\title{
Understanding Infanticide in Context: Mothers Who Kill, 1870-1930 and Today
}

Michelle Oberman

Santa Clara University School of Law, moberman@scu.edu

Follow this and additional works at: http://digitalcommons.law.scu.edu/facpubs

\section{Recommended Citation}

92 J. Crim. L. \& Criminology 707

This Article is brought to you for free and open access by the Faculty Scholarship at Santa Clara Law Digital Commons. It has been accepted for inclusion in Faculty Publications by an authorized administrator of Santa Clara Law Digital Commons. For more information, please contact sculawlibrarian@gmail.com. 


\title{
UNDERSTANDING INFANTICIDE IN CONTEXT: MOTHERS WHO KILL, 1870- 1930 AND TODAY
}

\author{
MICHELLE OBERMAN ${ }^{*}$
}

As a result of these conditions [poverty, stigma, joblessness, the absence of daycare, etc.], the mother very frequently seeks to relieve herself of the child's care by turning heaven and earth to get rid of it honorably, and if this fails, abandons it or takes its life.

\section{INTRODUCTION}

On July 29, 1911, the Chicago Tribune reported the story of a Miss Mary Stastch. An immigrant from Austria, Stastch was arrested in connection with the death of her three-week-old baby, which was found behind a residence in the city. The twenty-one-year-old mother stated that, after leaving the county hospital with her newborn, she wandered about Chicago for two days with the baby in her arms, seeking work. She could find nothing to do. On the afternoon of the third day, she claimed that the baby dropped from her arms. She grabbed the baby's bonnet string as it fell, which then pulled tightly around the baby's neck. She felt too weak to pick up the child immediately, and when she finally lifted it, she found that it was dead. Too poor to bury it, Miss Stastch carried the body to 1546 Carroll Avenue, where she abandoned it. ${ }^{2}$

For almost a decade, I have followed cases involving contemporary women in the United States who kill their children. Infanticide in our present society seems to be an anachronism, given our relative wealth and the widespread options for women seeking to avoid pregnancy or parenting. Cases like that of Miss Stastch belong to another era-one which seems as distant to us as the yellowing photos Miss

\footnotetext{
* DePaul University College of Law

' C.C. Carstens, Fate of Children Born Out of Wedlock, NEw Boston, Oct., 1911, at 211, quoted in W.H. Slingerland, Child Placing in Families 166 (1919).

${ }^{2}$ Abandoned Baby's Body Found: Mother Arrested, CHI. TRuB., July 29, 1911, at 3.
} 
Stastch might have carried with her from the old country. And yet, as I will explain in the course of this essay, in many important ways, her plight remains a contemporary one and is replicated day after day in cities and towns across this country.

The path to understanding the terrible crime of infanticide, both in bygone eras and in our own, lies in examining the circumstances that shape the lives and realities of mothers. To date, my research on infanticide has consisted of collecting stories from the media about mothers who kill their children, and fleshing them out as completely as possible by tracing their resolution through subsequent news stories, and also through the legal system. Occasionally, I have become involved in these cases as a scholar and a lawyer. In one instance, I interviewed and ultimately befriended a young woman accused and convicted of killing her newborn baby. In another case, I worked on a clemency petition and testified at a hearing on behalf of a woman serving a life sentence for killing her young child while suffering from postpartum psychosis.

Over the course of time, I have identified a distinct set of patterns in contemporary cases involving women who kill their children. In addition, my close examination of the circumstances surrounding these cases reveals a profound commonality that links these seemingly unrelated crimes. Specifically, infanticide may be seen as a response to the societal construction of and constraints on mothering.

The opportunity to juxtapose this contemporary vision of infanticide with the historical data arising out of the Chicago Homicide Database is helpful in several ways. First, this new historical data reveals several surprising shifts in the patterns of infanticide killings over the course of time. Second, it helps to lend perspective and clarity to the contemporary crime of infanticide. Finally, and most importantly, it provides powerful support to my earlier point: historically, as well as today, infanticide may be seen as a response to the societal construction of and constraints on mothering.

This essay begins with a brief overview of the patterned nature of contemporary infanticide cases in the United States. I then turn to the historical data, exploring both the striking similarities and the marked differences discovered when comparing today's cases with patterns of infanticide between 1870 and 1930. Finally, I consider the lessons we can glean from these cases in terms of the relationship between society, the structure of motherhood and the crime of infanticide. 


\section{PATTERNS IN CONTEMPORARY AMERICAN INFANTICIDE}

My contemporary research is compiled in a book I co-authored on infanticide, which draws on a database of 219 cases occurring between 1990 and $2000 .^{3}$ Of these cases, approximately seventeen percent involve babies who were killed within the first twenty-four hours of life, or "neonaticide" cases. ${ }^{4}$ The other eighty-three percent involve the deaths of infants any time after the first twenty-four hours of life. I refer to these cases generically as "infanticide." I begin with a description of neonaticide.

\section{A. CONTEMPORARY NEONATICIDE}

An extraordinary number of cases involving mothers who kill their children occur within the first twenty-four hours of the child's birth. In medical circles, these cases are termed "neonaticides," and the patterns surrounding these cases are both remarkably consistent, and also quite distinct from those surrounding the infanticide deaths of older infants and children. ${ }^{5}$

Women who commit neonaticide tend to be relatively young, and the overwhelming majority of these women are unmarried. ${ }^{6}$ For example, although the ages of the women involved in the thirty-seven neonaticide cases included in our book ranged from fifteen to thirtynine, the average age was nineteen. ${ }^{7}$ All but one of these cases involved unmarried women, and the overwhelming majority of the men who fathered these infants were completely absent from the women's lives by the time they gave birth. ${ }^{8}$

In addition to being isolated from their sexual partners, these women also were isolated from family and friends, fearing that disclosure of their pregnancy would jeopardize their already tenuous links to their support systems. Newspaper accounts often note the role played by fear in neonaticide cases. These fears include concerns such as getting kicked out of their parents' homes should their

\footnotetext{
${ }^{3}$ See Cheryl Meyer \& Michelle Oberman, Mothers Who Kill Their Children: Understanding the ACTS OF MOMS From SUSAN SMITH tO THE "Prom MOM" (2001). A more comprehensive look at the legal system's approach to contemporary infanticide cases appears in Michelle Oberman, Mothers Who Kill: Coming to Terms with Modern American Infanticide, 34 AM. CRIM. L. REV. 1 (1996).

${ }^{4}$ MeYer \& OBERMAN, supra note 3 , at 38.

${ }^{5}$ See Philip Resnick, Murder of the Newborn: A Psychiatric Review of Neonaticide, 126 AM. J. PSYCHIATRY 1414 (1970) (coining the term "neonaticide").

${ }^{6}$ See MEYER \& OBERMAN, supra note 3, at 41-50 (summarizing current research).

${ }^{7}$ Id. at $47-48$.

${ }^{8} \mathrm{Id}$. at 48 .
} 
pregnancies be discovered, or being exposed as an undocumented person. ${ }^{9}$ Financial insecurity also plays a role in these cases. In spite of the fact that the girls and women who commit neonaticide reflect the full range of socio-economic backgrounds, when one considers their personal financial resources, as distinct from those of their families, they are invariably quite vulnerable. ${ }^{10}$ This factor is quite important because these women are so convinced that having a baby will jeopardize their current living situations.

Women and girls who commit neonaticide tend to be exceedingly passive, and they respond to pregnancy with a combination of denial, wishful fantasy, and terror. ${ }^{1 /}$ In short, they are paralyzed and unable to settle on a course of action for responding to their pregnancies. Instead, when interviewed later, they report that they spent their pregnancies living day to day, focusing on the banal details of their lives, and hoping that the pregnancy would simply disappear, or that someone else would notice their condition and take charge of the situation. $^{12}$ There is a striking absence of trusted confidants in the lives of these girls and women, adding credence to their perception that they have few resources or options to assist them in responding to this pregnancy. ${ }^{13}$

An equally dramatic set of patterns surrounds the circumstances that lead to these infants' deaths. Virtually all neonaticide cases involve women who confuse the initial stages of labor with a need to defecate. They proceed to spend hours alone, most often on a toilet, often while others are present in their homes. They endure the full course of labor and delivery silently - a shocking feat given the typical noisiness of the birthing process. ${ }^{14}$ After delivering their babies, the women's behavior ranges from exhaustion to panic. Many of these babies drown in the toilet, while the woman is either passed out, recuperating from childbirth, or in some cases, frantically cleaning the room. In some cases, the women suffocate or strangle the baby to prevent it from crying out. 15

\footnotetext{
${ }^{9} I d$. at $49-50$.

${ }^{10}$ See Oberman, Mothers Who Kill, supra note 3, at 23.

"See MEYer \& OBERMAN, supra note 3, at 42-46.

${ }^{12}$ For a description of one young woman's account of the months preceding the neonaticide death of her child, see Oberman, Mothers Who Kill, supra note 3, at 53-64.

${ }^{13}$ See Meyer \& Oberman, supra note 3, at 56-57; See also Oberman, Mothers Who Kill, supra note 3 , at 24.

${ }^{14}$ See Oberman, Mothers Who Kill, supra note 3, at 24-25.

${ }^{15}$ Id.
} 
Society responds to the crime of neonaticide in a surprisingly wide variety of manners. Despite the consistently harsh rhetoric of outrage that these cases generate, some juries and judges are quite lenient with these defendants. It is not unusual for those who investigate these cases to elect not to file criminal charges, or for women convicted of neonaticide to receive probation rather than a prison sentence. $^{16}$ Indeed, in many countries throughout the world infanticide laws specify that no charge higher than manslaughter may be brought against these women, and a probationary sentence, including mandatory counseling, is the standard response to these cases. ${ }^{17}$ On the other hand, many of these women receive exceptionally harsh punishments and are forced to serve lengthy sentences for their crimes. ${ }^{18}$

In a sense, the range of responses to neonaticide within the criminal justice system might reflect, or even stem from, the polarized debate over abortion in society at large. For those who see abortion as murder, the crime of neonaticide may be seen as the natural product of a culture that has embraced permissive sexual norms and legalized abortion. ${ }^{19}$ It may be easier for those holding these views to condemn neonaticide in outright terms than it is for those who are supportive of a woman's right to terminate an unwanted pregnancy.

Pro-choice views, however, can go both ways. On the one hand, those who are pro-choice may be inclined to condemn neonaticide in as harsh a manner as those who are anti-choice. Pro-choice advocates work hard to draw a bright line between fetuses and children, asserting that the latter, but not the former, are entitled to the full range of legal rights and protections. As the prolonged debate over "partial-birth" abortions demonstrates, any attempt to countenance the murder of born children would undermine that dichotomy, and threaten the ideological stance, as well as the actual coalition, of those who support legalized abortion. ${ }^{20}$

\footnotetext{
${ }^{16}$ See id. at 25-26 (describing the range of criminal penalties sought in their cases); see also MEYER \& OBERMAN, supra note 3, at 58-60.

${ }^{17}$ Oberman, Mothers Who Kill, supra note 3, at 17-19.

${ }^{18}$ For a discussion of the broad range of responses to thesc cases, see MEYER \& OBERMAN, supra note 3, at 58-60.

${ }^{19}$ For a sampling of opinions reflecting this sentiment, see Kevin Lamb, Trial Touched on Some Emotional Issues, Dayton Daily News, June 23, 1995, at B1.

${ }^{20}$ For a sample of the debate over "partial-birth" abortion, see, e.g., Meredith R. Henderson, Stenberg v. Carhart: "Partial-Birth" Abortion Bans and the Supreme Court's Rejection of the "Methodical" Erasure of the Right to Abortion, 79 N.C. L. REv. 1127 (2001); Ann MacLean Massie, So-Called "Partial-Birth Abortion" Bans: Bad Medicine? Maybe. Bad Law? Definitely!, 59 U. PITT. L. Rev. 301 (1998); James Bopp, Jr., J.D. and Curtis R. Cook,
} 
On the other hand, pro-choice individuals are, by definition, more inclined to consider the circumstances surrounding a woman's pregnancy when weighing the moral wrong of abortion. As such, it seems likely that they might view neonaticide cases from the defendant's perspective, noting the factors that gave rise to her crime and perhaps feeling some sympathy for her plight.

Either way, it seems clear that Americans respond to these cases in a highly charged manner, tending to see them as isolated, horrific, and incomprehensible acts, rather than as commonplace patterned killings, as revealed when one looks more closely at the underlying facts. $^{21}$ What is missed in this analysis is the extent to which neonaticide cases are indeed comprehensible. As I've argued elsewhere:

$[\mathrm{N}]$ eonaticide may be seen as a "mothering" decision. Typically, these cases involve young pregnant women, who determine, correctly or not, that they would be completely cut off from their social support network were they to disclose their pregnancies. More importantly, they are convinced that they would be exiled from their families, their homes, and their communities were they to attempt to parent their child alone. The terrifying thought of parenting with no money, limited education, few job options, and no one to love and care for them, surely contributes to the panic and denial of pregnancy typically manifested by this population. $^{22}$

\section{B. CONTEMPORARY INFANTICIDE CASES}

As for the cases of infanticide occurring after the first twentyfour hours of life, there is tremendous variation. These cases range from the deaths of infants at the hands of mothers suffering from acute or chronic mental illness, including such ailments as postpartum psychosis or schizophrenia, to deaths resulting from a mother's chronic abuse or neglect of her child. ${ }^{23}$ Despite the great variation in

M.D., Partial-Birth Abortıon: The Final Frontter of Abortion Jurisprudence, 14 IssuEs L. \& MED. 3 (1998).

${ }^{21}$ See Oberman, Mothers Who Kill, supra note 3, at 4-5, 27-30 (discussıng media portrayal of neonaticide).

${ }^{22}$ MeYer \& OBerman, supra note 3, at 169.

${ }^{23}$ Our book divides infanticide cases into four categories: abuse-related filicide (cases involving mothers who killed their child during a physical assault), filicide due to neglect (cases involving women who did not purposely kill their child, but either failed to attend to the child's basic needs, or were irresponsible in their reaction to the child's behavior), assisted/coerced filicide (cases involving mothers who acted along with their partners, or in some cases failed to intervene to stop their partners from killing their children), and purposeful filicide in which the mother acted alone (cases involving mothers, the overwhelming ma- 
factual backgrounds behind the many cases of contemporary infanticide, a close look at these cases reveals consistent patterns in the circumstances surrounding these crimes.

There are multiple social stressors that impact on the lives of the mothers who commit infanticide. These women tend to be relatively young mothers, although not as young as those who commit neonaticide, and they are disproportionately single or involved in unstable relationships. ${ }^{24}$ The vast majority of these women are poor and isolated from support systems such as extended family, church, or a strong neighborhood or community. ${ }^{25}$

Others have noted the interdependent relationship between maternal social support and child maltreatment, showing that mothers who abuse their children report greater isolation from family and friends, and rate the quality of their friends' support lower than do nonabusive mothers. ${ }^{26}$ The problems generated by maternal isolation and a lack of social support are compounded by factors such as limited education and underlying mental health problems. ${ }^{27}$ Indeed, mental health issues, including chemical dependency, are present in a significant percentage of contemporary infanticide cases. These issues play an obvious role in infanticide cases involving mothers suffering from chronic mental illness or postpartum mental disorders, but they are present in other cases as well. For instance, it is clear that the vast majority of women in my book who purposefully killed their children were experiencing some form of extreme emotional distress at the time of their crimes. ${ }^{28}$ Although many of them would not have met the legal definition of insanity, the reports of their cases suggest that most of them likely suffered from major depression,

jority of whom suffered from some form of mental illness, who purposefully killed their children). See id. at 36-38.

${ }^{24}$ The modal age of the infanticidal mothers in my original work was twenty-one. See Oberman, Mothers Who Kill, supra note 3, at 32. Regarding the issue of relationships, my book notes that a full forty-two percent of the infanticide cases falling into the "purposeful" category involved women who had experienced a recent break up, separation, or divorce prior to the murders. See also Meyer \& OBERMAn, supra note 3, at 88 . The women in the other categories were even more likely to be single or not currently in a relationship with the father of their children.

${ }^{25}$ MeYer \& OBerman, supra note 3, at 110.

${ }^{26}$ See, e.g., S.J. Bishop and B.J. Leadbeater, Maternal Social Support Patterns and Child Maltreatment: Comparison of Maltreating and Nonmaltreating Mothers, 69 AM. J. ORTHOPSYCHIATRY 172 (1999).

${ }^{27}$ For example, one study reveals that mothers accused of child neglect were far less likely to have completed high school. See Robert M. Brayden et al., Antecedents of Child Neglect in the First Two Years of Life, 120 J. PEDIATRICS 426 (1992).

${ }^{28}$ MEYER \& OBERMAN, supra note 3, at 93. 
anxiety, and even psychosis. ${ }^{29}$ A full thirty-four percent of those who killed their children in cases involving maternal neglect suffered from chemical dependency. ${ }^{30}$

Mental health issues are central to understanding not only the genesis of infanticide, but in a curious way they are equally central to society's response to this crime. Unlike the neonaticide cases, in which there is great variation in the criminal charges leveled against the accused women, women who commit infanticide are almost always charged with murder. Nonetheless, the outcomes of these cases are remarkably varied, ranging from death sentences in some cases to probation in others. ${ }^{31}$ Despite this broad spectrum of dispositions, there is a pattern underlying these outcomes. Scholars have labeled this pattern the "mad" versus "bad" phenomenon. ${ }^{32}$ To the extent that she is seen as "bad" rather than "mad," a woman convicted of killing her children is more likely to receive a harsh sentence. For example, consider the case of Jeanne Anne Wright, who was sentenced to four consecutive life terms in the drowning deaths of her children, including a young baby. The New Jersey court described her actions as "occurring "over a period of several hours and after much thought," and attributed her motive to a fear that the father of the children might attempt to gain custody of them. ${ }^{33}$

The category of "mad" women extends far beyond cases involving confirmed diagnoses of insanity, or even of postpartum mental disorders, and helps to explain the relatively light sentences given to some who are convicted of infanticide. For example, consider Susan Smith, who killed her two sons in the fall of 1994 and then fabricated a story about an African American kidnapper having taken them, prior to confessing to her crime. ${ }^{34}$ Many in the media cast her as the quintessential "bad" woman, labeling her a "promiscuous, sexually exploitive adult ... [ [who] ended her marriage to the poor boy who loved her and gambled on a rich boy who didn't. When it all came

\footnotetext{
${ }^{29} \mathrm{Id}$.

${ }^{30} / d$. at 114 .

${ }^{31}$ Obcrman, Mothers Who Kill, supra note 3, at 42.

${ }^{32}$ Ania Wilczynski, Images of Women Who Kill Their Infants: The Mad and the Bad, 2 WOMEN \& CRIM. JUST. 71-72 (1991).

${ }^{33}$ State v. Wright, 483 A.2d 436, 524 (N.J. Super. Ct. L. Div. 1984). See also Leigh B. Beinen et al., The Reimposition of Capital Punishment in New Jersey: The Role of Prosecutorial Discretion, 41 RUTGERS L. REV. 27, 93-94 (1988) (discussing the complications surrounding the State's efforts to secure Ms. Wright's guilty plea in exchange for avoiding the death penalty).

${ }^{34}$ Gail Wescott, The Reckoning, PEOPLE, Aug. 7, 1995, at 73.
} 
apart she committed an act of savagery that defies understanding., ${ }^{, 35}$ However, after hearing testimony regarding her father's suicide, the years of sexual abuse suffered at the hands of her stepfather, her social isolation, and her depression and anxiety, the "death-qualified" jury refused to endorse this simplistic vision of her and instead sentenced her to life in prison, with eligibility for parole. ${ }^{36}$

At a common sense level, it is not surprising that, to the extent that mothers who kill their children are viewed as crazy or sick, judges, juries, and society at large are relatively sympathetic. ${ }^{37}$ Indeed, it may seem self-evident that " $[\mathrm{m}]$ others in our society simply do not kill their children unless they are seriously disturbed individuals." ${ }^{38}$ It is critical to note, however, that these crimes do not occur solely because of a mother's mental impairment. Rather they result from a combination of the mother's vulnerable mental status and the social isolation and other factors that shape the context in which she is expected to parent. No less than with neonaticide cases, contemporary infanticide cases reflect reactions to the structure of motherhood and the constraints that this society places on mothers.

\section{Mothers who Killed Their Children: Chicago, 1870-1930}

When I first obtained the carefully transcribed volumes of homicides recorded by the Chicago Police Department between the years of 1870 and 1930, I was stunned. ${ }^{39}$ Page after page of stark descriptions of deaths from a long-gone era left me cold. How could I, who had never lived in that time, understand the lives and deaths of those whose names crossed these pages? In many cases, the old police reports were far more complete than the media accounts of infanticide that I used in my contemporary work. They provided the name, age, and race of the defendant and her victim. Often they noted her circumstances and her explanation for her acts. And unlike most con-

${ }^{35}$ Tom Morgenthau, Condemned to Life, Newsweek, Aug. 7, 1995, at 19.

${ }^{36}$ Brad Warthen, Editorial, Jury's Wisdom Beats 'Dittohead Justice,' Denver Post, Aug. 10,1995 , at B11.

${ }^{37}$ Professor Michael Perlin calls infanticide defendants "empathy outliers," noting that in spite of the increasingly limited reach of the insanity defense, these women tend to capture juries' sympathy and lenience. Michael L. Perlin, The Jurisprudence of the InSanity DEFENSE 192 (1994).

${ }^{38}$ Amy L. Nelson, Comment, Postpartum Psychosis: A New Defense?, 95 Dick. L. REV. 625, 625 (1991) (quoting report prepared for sentencing hearing in Pennsylvania v. Comitz, 530 A.2d 473 (Pa. Super. Ct. 1987)).

${ }^{39}$ Leigh Bienen, Chicago Homicide Project, Homicide Cases 1870-1930, Book One (2000) (unpublished manuscript) (on file with author) [hereinafter Chicago Homicide Database]. 
temporary cases, these reports often concluded by revealing the disposition of each case. ${ }^{40}$

I found myself wanting to know more about these women, their lives, and the social structures that shaped the work and the world of mothering. In an effort to answer these questions, I delved into the rich social history of Chicago in this era-a history recorded in detailed scholarly works, in newspaper articles, in appellate court cases, and even in the fiction of those years. This work, in conjunction with my past work on infanticide, serves as the foundation for my observations and interpretations of the line of infanticide cases emerging from the Chicago Homicide Database.

There are 185 cases in this database involving mothers who killed their children. Just as was the case with my earlier work on infanticide, these cases may be divided into neonaticide and infanticide. Once classified in this manner, a stunning set of patterns emerges. First, the neonaticide cases seem quite reminiscent of contemporary neonaticide. They are shockingly numerous, however, and the vast majority of the cases are unsolved. Second, among the remaining cases of infanticide there are a large number of cases involving women who killed their children and then committed suicide. These homicide-suicide cases are a rarity in contemporary society, and yet they seemed almost commonplace in this bygone era. The following sections will describe the patterns in neonaticide and infanticide that emerge from this rich historical record.

\section{A. NEONATICIDE CASES: CHICAGO, 1870-1930}

Of the 185 cases in the database, a full 136 (seventy-four percent) involved neonaticide. Of these, 115 cases were unsolved, in that the reports note only that a newborn child's body was found but no defendant was identified. ${ }^{41}$ In light of all that is known about

${ }^{40}$ One of the greatest frustrations in researching contemporary infanticide cases stems from the waxing and waning of media attention. Cases that command front-page stories when the crime occurs often disappear without a trace, when months later, the defendant pleads guilty to a lesser offense and the case is quietly resolved. Bccause there are hundreds of cases like this every year and because they are neither tried nor appealed, the work involved in tracking them would be overwhelming. As a result, my studies have been limited to those cases that the media elects to follow most thoroughly.

${ }^{41}$ See Chicago Homicide Database, supra note 39 . The relatively high percentage of unsolved cases is not surprising. Even assuming police had adequate staffing to conduct investigations, in this era they lacked the requisite technology, such as tracing suspects through blood, hair, and DNA specimens, that facilitates the identification of defendants in similar cases today. Indeed, other sources indicate that this count of 115 may be an underestimate of the actual total number of unidentified newborns found dead in Chicago during this time 
neonaticide, it is fair to assume that the mothers of these children were the primary parties to these homicide deaths. ${ }^{42}$ Of course, it is possible that the woman who killed her newborn was aided, or even coerced in her actions, by her family and/or lover. Indeed, some reported cases involving neonaticide are predicated upon the argument that others were responsible for the actual killing of the child. ${ }^{43}$ Nonetheless, given the proximity of the infant's birth to its death in these cases, as well as all that we know about this crime from contemporary sources, it is fair to assume that, in the vast majority of these unsolved cases, mothers were involved in bringing about the deaths of their infants.

There are twenty-one cases in the database in which the defendant is identified. "These cases reveal a pattern that is remarkably similar to contemporary neonaticide cases. The defendants are unmarried women who conceal their pregnancy from others and then deliver their babies alone, unattended by assistants of any sort. Just as is common in contemporary cases, the reports reveal that the babies died as a result of drowning, smothering, or abandonment.

A typical case is \#2051, involving Ms. Victoria Royers. Ms. Royers was a single woman, twenty-two years old, who confessed to having thrown her newborn infant into a "water closet" at a downtown restaurant. Another similar case involves Mrs. Mabel Huson, a twenty-two-year-old woman who had been separated from her husband for two years. She confessed to having suffocated her newborn, and to abandoning the corpse in an alley. ${ }^{44}$ From the little we can glean from the reports of these cases, they are indistinguishable from contemporary cases. Both involved women who lived alone, apparently without the support of the men who impregnated them. They endured labor and delivery alone, and then attempted to conceal the evidence of their pregnancies by killing their newborns.

If we are truly to understand these crimes, and the women who committed them, however, it is critical to view them in the context of

frame. Beginning in 1906, the Chicago Police Department began listing in its annual reports the number of fetuses found. From 1906 to 1920 , the police discovered between fifty-one and seventy-nine bodies each year. Jeffrey Adler, "Halting the Slaughter of the Innocents": The Civilizing Process and the Surge in Violence in Turn-of-the-Century Chicago, 251 SoC. SCI. Hist. 29, 41 (2001).

${ }^{42}$ See supra notes 6-8 and accompanying text.

${ }^{43}$ See, e.g., Campbell v. State, 42 N.E. 123 (Ill. 1895) (recounting how a mother asserted that the defendant, father of her newborn infant, took the baby from her within minutes of its birth, and returned thirty minutes later without it).

${ }^{44}$ Chicago Homicide Database, supra note 39, Case No. 10,120. See also Mother Admits Killing Her Day Old Baby Boy, CHI. TruB., Feb. 23, 1929, at A3. 
their unique place in time. There is a wonderfully rich historical record regarding women's lives in Chicago in this era. This body of work helps to depict the world in which these women lived, socialized, engaged in sexual relations, endured pregnancy, and contemplated motherhood. In short, it enables us to understand the circumstances surrounding neonaticide in this era. Although it is impossible to know for certain which, if any, of the following factors played a role in any given case of neonaticide, these various conditions most certainly shaped the backdrop against which these crimes were played out.

\section{Urban Life and Lifestyles}

The years from 1870 to 1930 witnessed a tremendous influx of women wage earners to urban centers around the United States. During this era, the female labor force in Chicago increased from 35,600 to 407,600 (over a $1000 \%$ increase). ${ }^{45}$ This rate was over three times as great as the increase in the female labor force nationally. ${ }^{46}$

The newcomers included immigrants and native-born women, of both working and middle class backgrounds. When they came to the city, many young women lived alone. In 1900, Chicago had over 22,000 wage-earning women living away from home. This figure represented one-fifth of all wage-earning women in the city, and does not include women working as domestics and boarding in employers' homes. $^{47}$

Women came to the cities seeking work, as well as a broader set of life options. Women who opted not to live with families had an abundance of boarding houses and furnished rooms from which to choose. The boarding houses aimed to provide family-like supervision of young women's virtue. They generally failed in this endeavor. The furnished rooms for rent in several large districts of the city offered residents complete freedom to come and go without supervision.

Young men who lived apart from family generally earned wages sufficient to support themselves and often sufficient to support a family as well. In contrast, employers assumed that all working women lived in families where working males provided them with partial support. Thus, virtually everyone agrees that women's wages during

\footnotetext{
45 JOANNE MEYEROWITZ, WOMEN ADRIFT 4-5 (1988)

${ }^{46} \mathrm{Id}$.

${ }^{47} \mathrm{Id}$.
} 
this era were grossly inadequate and that it was all but impossible to pay room and board out of the average woman's wage. In fact, a 1908 federal government survey of store and factory workers found that over half of single working women in Chicago earned less than eight dollars per week, which was widely acknowledged as the subsistence wage. ${ }^{48}$

Theodore Dreiser's Sister Carrie provides a vivid depiction of the impact of these constraints on the lives of young women who migrated to Chicago. ${ }^{49}$ In this novel, Carrie moves to the city from rural Wisconsin, intending to live with her married sister. An ambitious young woman, she quickly tires of this cloistered living arrangement, and yet she is unable to find work that would permit her to live alone and support herself. She meets a decidedly predatory salesman, who correctly anticipates her inability to support herself. "'These girls,' [he says] and waved an inclusion of all shop and factory girls, 'don't get anything. Why, you can't live on it, can you?" 50 Ultimately, he offers to set her up in an apartment of her own, paying her rent and buying her luxurious clothes to wear.

\section{Sexuality}

The role of sexuality in the lives of young, urban women in this era is shaped in part by the realities of housing and salary arrangements. Throughout this era, virginity remained a critical element in assessing a woman's value, but sexual norms shifted over the course of the years between 1870 and 1930, such that the value of a woman's sexuality was not restricted solely to marriage. This is not to say that women became promiscuous during this era. Instead, aside from some sexual experimentation in the "bohemian" circles of the 1920's, sexual activity was seen as a valuable commodity for women-as something that might be bartered away in exchange for, say, a place to live, fine clothes, or perhaps a promise to marry. ${ }^{51}$

Many women living alone, attempting to support themselves on inadequate salaries, used sexual activity as a means of supplementing their meager incomes. Scholars of this era have identified dating

\footnotetext{
${ }^{48}$ Id. at 37 .

49 Theodore Dreiser, Sister Carrie (Modern Library 1999) (1900).

${ }^{50} \mathrm{Id}$. at 82 .

${ }^{51}$ See Jane E. Larson, "Women Understand So Little, They Call My Good Nature 'Deceit '": A Feminist Rethinking of Seduction, 93 COLUM. L. REV. 374 (1993); See MEYEROWITZ, supra note 45, at 124 ("More recent studies of sexual practices reveal that, by the 1920s, rates of extramarital intercourse had indeed increased among middle-class women.").
} 
practices designed by young women to compensate for their financial exigencies by providing them food, clothing, and perhaps shelter, in exchange for giving their male partners companionship and occasional sexual favors. It is critical to note that these women did not consider themselves prostitutes. For example, a 1911 federal report "noted the lack of compunction" with which women traded on their sexuality by stating, "They simply take this means of securing more amusements, excitements, luxuries, and indulgencies [sic] than their wages would afford them. They are not promiscuously immoral."52

One certain outgrowth of the relaxation of norms surrounding premarital sexuality was an increase in the incidence of unplanned pregnancies. Although effective contraception existed in the form of condoms and rudimentary diaphragms, access to contraception was challenging. ${ }^{53}$ Beginning in the 1870 's, federal and state laws prohibited the vending of any contraceptive device. Many state laws prohibited physicians from prescribing contraceptives even to married couples, and access to prescription contraception was virtually impossible for the unmarried.

There was widespread ignorance among married and unmarried women regarding mechanisms for preventing unwanted conception. Margaret Sanger's groundbreaking effort to spread knowledge of birth control in the 1910's and 1920's resulted in her arrest on multiple occasions. ${ }^{54}$ Her published collection of letters written to her by women during this era is a testimony to women's desperate yearning to gain control over their reproductive lives. ${ }^{55}$

Even if women had access to contraception, however, none of the available methods was infallible. As a result, unplanned pregnancy was commonplace, and the demand for access to abortion was assured.

\section{Abortion and Adoption Practices}

Prior to the 1870's, abortion was not a crime in the United States. ${ }^{56}$ In the aftermath of laws that made abortion a crime, there

\footnotetext{
${ }^{52}$ MYEROWITZ, supra note 45, at 124.

${ }^{53}$ For a fine depiction of the issues surrounding contraception during this era, see ANDREA TONE, Devices \& Desires: A History of CONTRACEPTIVES IN AMERICA (2001).

54 James Reed, The Birth Control Movement And AMERICan SOCIETY: From Private Vice to Public Virtue 107-08 (1978).

${ }_{55}$ Margaret Sanger, Motherhood in Bondage (1928).

${ }^{56}$ For a wonderfully rich history of abortion in America, and the events leading to its criminalization, see JAMES MOHR, ABORTION IN AMERICAN (1978).
} 
developed a widespread illegal abortion industry. Leslie Reagan's rich history of that industry and of the women who sought out its services demonstrates that abortion remained widely practiced in doctors' and midwives' offices, and in women's homes. ${ }^{57}$ Nonetheless, obtaining an illegal abortion required a network of friends and relatives to locate and pay for the operation. An abortion might cost anywhere from $\$ 50$ to $\$ 100$-a tall order for a woman living on less than $\$ 8$ per week. ${ }^{58}$ Additionally, illegal abortion was a high-risk procedure, and although it is impossible to know what percentage of illegal abortions resulted in death, it is clear that abortion was more dangerous than childbirth, causing hundreds, if not thousands, of deaths each year. ${ }^{59}$

A determined and resourceful pregnant woman could have identified an abortionist and borrowed the money needed to secure an illegal abortion in Chicago. A more passive or socially isolated woman might have desired an abortion but have been unable to locate or afford one. Likewise, she may have been immobilized by wishful thinking about her lover, or by the difficult tradeoff between avoiding unwanted pregnancy and risking her life by submitting to a potentially incompetent provider of this illegal service.

An alternative resolution for an unplanned, unwanted pregnancy was to relinquish the baby for adoption. ${ }^{60}$ Informal adoptions seem to have been the norm in this era, and many young women found family members or close friends who were willing to take on the burden of another child. ${ }^{61}$ There are numerous barriers, however, that

${ }^{57}$ Leslie Reagan, When Abortion was a Crime (1997).

${ }^{58}$ Id. at $29,32$.

${ }^{59}$ Id. at 77 .

${ }^{60}$ The first formal adoption law was passed in 1851, and for many years adoptions were poorly recorded and viewed as the "last resort" for social workers. "The combination of cultural, medical, and social stigma surrounding adoption during the first quarter of the twentieth century kept the number of potential adoptive parents relatively low and thus depressed the number of children who were adopted." E. WAYNE CARP, FAMILY MATTERS: SECRECY AND DISCLOSURE IN THE HISTORY OF ADOPTION 20-21 (1998). However, some mothers and adoptive parents easily and anonymously circumvented the adoption institutions by using unregulated, underground means. See id. at 1-35 (describing the transformation of adoption into a regulated institution).

${ }^{61}$ During this era, adoptions were largely unregulated, socially disfavored and stigmatizing. Most child-placing organizations refused children if they had any family or could be "properly cared for by their own people." CARP, supra note 60, at 17. Because women with children were likely to be turned away, families and friends were more accessible than the formal adoption process of the time. See id.; see generally CAROL B. STACK, ALL OUR KIN (1974) (describing of African-American women living in tightly-knit communities and "adopting" the children of family and neighbors). 
stop women from placing their babies with adoptive parents, historically as well as today. Arranging for one's baby to be adopted requires acknowledging, both to oneself and to others, that one is pregnant, and requires that the woman involved actively assume responsibility for and control over her situation. ${ }^{62}$ It requires that she sacrifice any dreams of romance or reconciliation that she may harbor regarding this pregnancy. In short, it requires overcoming the very impulses of shame, fear, and irrationality by which women who commit neonaticide tend to be immobilized.

\section{Out-of-Wedlock Births: Stigma and Poverty}

The loss of virginity, particularly if coupled with pregnancy, could signal the demise of an unmarried young woman's hopes and plans for a bright future. This loss was all but guaranteed if her lover abandoned her. Bastardy laws of this era aimed to restrict childbearing to married couples by penalizing children who were born out of wedlock. ${ }^{63}$ Women, particularly white middle-class women, who bore children out of wedlock were considered unmarriageable and

\footnotetext{
${ }^{62}$ With regard to the contemporary population of girls who relinquish their babies for adoption, they can generally be described as:

[Y] oung women who have the information necessary to do so; have made rather definitive decisions about their future in terms of education and employment (and, thus, see raising a chıld as an obstacle to the completion of these goals); and have clear and defintive support of family or friends (specifically in that the famıly's cultural background and belıefs do not forbid such a choice).
}

Oberman, Mothers Who Kill, supra note 3, at 61. This description is far from compatible with the passive, isolated, and procrastinating personalities associated with neonaticide cases.

${ }^{63}$ Bastardy statutes were civil laws that had quasi-criminal features, such as the ability to arrest fathers who failed to support their out-of-wedlock offspring. These U.S. laws stemmed from British Poor Laws, originally passed in 1576, which mandated a paternal as well as a maternal obligation to support a non-marital child. The laws also mandated the punishment of both the mother and father of these children, thus creating further incentive to conceal a pregnancy and the resulting child. See Karen A. Hauser, Comment, Inheritance Rights for Extramarital Children: New Science Plus Old Intermediate Scrutiny Add Up to the Need for Change, 65 U. CIN. L. REv. 891 (1997). For more on bastardy laws, see Michael Grossberg, GOVERning the HeARTH: LAW AND tHe FaMily IN NINETEENTH-CENTURY AMERICA 218-28 (1985) (describing central tenets of bastardy laws).

Until as recently as the 1960 's, non-marital children had no inheritance rights, were not considered "dependants" eligible to receive workmen's compensation benefits, and could not receive Social Security benefits for a parent's disability. For a detailed evolution of nonmarital children's equal protection rights, see Susan E. Satava, Discrimination Against the Unacknowledged Illegitimate Child and the Wrongful Death Statute, 25 CAP. U. L. REV. 933 (1996) and JenNy Teichmann, IlLeGiTimaCy (1982) 
were exiled to fringes of their communities. ${ }^{64}$ One of the neonaticide cases in the database provides a vivid illustration of the manner in which this backdrop might influence a woman facing an unplanned pregnancy. In 1887, a woman referred to only as Mrs. Daniel Long was arrested and charged in the homicide death of her newborn son. The police learned that she had been seduced and impregnated by a man who refused to marry her. Then, when she was six months pregnant, she met and married another man. Her new husband was oblivious to her condition. Three months later, she gave birth to her child alone and then threw the infant into a manure box in a failed attempt to conceal the baby from her new husband. ${ }^{65}$

Mrs. Long's desperation becomes comprehensible if one acknowledges the likelihood that her new marriage would have ended once her husband learned that she had given birth to a baby fathered by another man. The prospect of single motherhood in this era was overwhelmingly grim. If the working wage was insufficient to support a woman alone, it clearly was insufficient to support a woman and her child. ${ }^{66}$ Women who had migrated to the city and then become pregnant might have been welcome to return to their rural homes and families. On the other hand, it is certain that some women left their families because of poverty or abuse or any of a number of reasons that might make such a return unacceptable. Even if she was willing to return, her family might be reluctant to accept the young woman and her baby back into their home, fearing that she would bring shame upon the household, and upon any marriageable siblings

${ }^{64}$ African-American mothers were more accepted by their communities through extended family and social networks. African-American reformers were "more likely than white reformers to emphasize universal (as opposed to criteria-restricted) benefits as well as programs for working women and their children .... Denied access to orphanages, old peoples' homes, clinics, and settlement homes serving whites. Blacks responded by establishing their own benevolent institutions." Sandra M. O'Donnell, The Care of Dependant AfricanAmerican Children in Chicago: The Struggle Between Self-Help and Professionalism, $27 \mathrm{~J}$. Soc. His. 763, 764-65 (1994). African American social charities and churches created services for mothers and children, such as day cares, educational programs, homes for single working women, and orphanages (drawing from communal, mutual aid traditions). See id.; see also Elna C. Green, Infanticide and Infant Abandonment in the New South: Richmond, Virginia 1865-19/5, 24 J. FAM. HIs. 187, 203 (1999) (describing how neighbors in AfricanAmerican communities would cover for young women suspected by police of killing their infants).

${ }^{65}$ Chicago Homicide Database, supra note 39, Case No. 1275.

${ }^{66}$ In Chicago at the turn of the century, over half of working women earned less than eight dollars a week, far below a liveable wage. Circumstances were worse for AfricanAmerican women, who often earned one dollar less per week than white women. MEYEROWITZ, supra note 45, at 34. 
the young woman might have left behind. ${ }^{67}$ Of course, women who were new immigrants to the country lacked the option of returning to their families and were forced to manage on their own.

If she was determined to stay in the city, a woman working to support herself and her child would need someone to care for her child. Daycare options were virtually nonexistent in this era. Women, and particularly white women, were expected to stay at home with their children. Women of color generally relied upon family members to care for their children while they worked lowpaying jobs. The only commercial daycare available existed in the form of the notorious "baby farms." These farms proliferated in urban centers as places where women could pay to leave children for day, a month, or even permanently. Unsurprisingly, these farms were associated with exceedingly high infant mortality rates and high fees and were not realistic daycare options for a mother seeking to ensure her child's well-being while she worked to support the child. ${ }^{68}$ Indeed, one of the cases in the database involves an infant who died when her skull was crushed. The infant had been staying at a baby farm, and the owner, Mrs. Nellie Campbell, was arrested and charged with murder but was ultimately acquitted in connection with the infant's death. ${ }^{69}$

There was no stable social umbrella for the poorest members of society in this era. No federal or state government programs offered money or access to health care for infants, children, and mothers.

${ }^{67}$ One author summarizes the situation faced by unmarried mothers as follows:

The disgrace which attached to unwed pregnancy in Victorian tımes was intense and allencompassing. Family and friends might cut off all relations, and the poor woman would be forced to leave her home and neighborhood to seek anonymity. The difficulties of trying to support herself and her child would have been nearly insurmountable because women's wages were not set high enough to support themselves, let alone dependent children. Unless she could find a charitable organization to take her in, prostitution would be her only resort.

Constance B. Backhouse, Desperate Women and Compassionate Courts: Infanticide in Nineteenth-Century Canada, 1984 U. TORONTO L.J. 447, 448 (1984).

${ }^{68}$ To get a sense of the popular perception of baby farms, see the 1890 report by muckraking journalist Jacob A. Riis, which noted that "baby-farms" fed the children sour milk and drugs to keep them quiet and allowed them to starve to death, with inexperienced doctors called in to record a false cause of death. JaCOB A. RiIs, How THE OTHER Half Lives 194-195 (1901); see also Lucy S. McGough and Annette Pelticr-Falahahwazi, Secrets and Lies: A Model Statute for Cooperative Adoption, 60 LA. L. REV. 13, 29-31 (1999).

${ }^{69}$ Chicago Homicide Database, supra note 39, Case No. 206. Nothing is known about the reasons for her acquittal. One might spcculate that, given the meager fees charged by baby farms, and the tacit understanding that babies placed with these farms might never be reclaimed, the jury felt that the defendant was not solely to blame for the baby's death. 
There were no housing projects or food subsidies to provide shelter and sustenance to those who could not afford it. Single women with children had to rely on charity. ${ }^{70}$ Given the stigma associated with sexuality and illegitimacy, a woman who conceived and bore a child out of wedlock was not a particularly attractive candidate for charity. $^{71}$

\section{Marriage and Unwanted Pregnancy}

Although the majority of neonaticide cases in the database that mention marital status describe single mothers, it is certain that some of the women who committed neonaticide were married. Some cases refer to the mothers as "Mrs." but fail to mention the husband or baby's father. ${ }^{72}$ Historically, poor married women (and men) have resorted to neonaticide as a desperate means of limiting family size. ${ }^{73}$ Margaret Sanger's book, Motherhood in Bondage, is filled with letters from married women, who wrote to her seeking advice and assistance in controlling the number and spacing of their children. ${ }^{74}$ These letters provide a vivid depiction of the quiet desperation of these young mothers, married as early as fourteen and debilitated by the toll of bearing one child after another over the course of their lives. More often than not, societies have been generous in their

${ }^{70}$ Private charities crusaded against poverty, but based their efforts on creating "proper" American families, not on providing relief to needy mothers and children. "A New York charity worker described the homes of the poor as 'nurseries of indolence, debauchers, and intemperance,' and their inhabitants as the 'moral pests of society.' Instead of recognizing these conditions as expected outcomes in overcrowded, impoverished communities, they became the antithesis of the proper home and the root of all social evil." MIMI ABRAMOVITZ, Under AtTaCk, Fighting BaCK: WOMEn and Welfare IN the United States 51-59 (2000); see also Linda Gordon, Pitied but not Entitled: Single Mothers and the HISTORY OF WELFARE 1890-1935 (1984).

${ }^{71}$ See, e.g., Ruth Crocker, I Only Ask You Kindly to Divide Your Fortune With Me: Begging Letters and the Transformation of Charity in Late-Nineteenth Century America, 6 Soc. POL. 131 (1999) (discussing the "bureaucratization and depersonalization of charity" which led to funding of institutions, not needy individuals). Literary descriptions of the soup kitchens and flop houses of the era typically depict all-male institutions, in which a woman and her child would have been completely vulnerable and unwelcome. See, e.g., DREISER, supra note 49 , at ch. XLV (depicting the demise of Hurstwood).

${ }^{72}$ See, e.g., Chicago Homicide Database, supra note 39, Case No. 1225 (involving a Mrs. Mary Kmak, who was accused of having thrown her newborn infant into a privy vault. The grand jury returned a no bill).

${ }^{73}$ See, e.g., MEYER \& OBERMAN, supra note 3, at 1-12 (providing a brief cross-cultural history of infanticide).

${ }^{74}$ See generally, SANGER, supra note 55. 
judgment of these women. ${ }^{75}$ Although it is impossible to tell from our database how many of the women accused of neonaticide were married, it is interesting to note that in the two neonaticide cases that mention married mothers, the grand juries refused to indict. ${ }^{76}$

\section{B. SOCIETAL RESPONSES TO NEONATICIDE: $1870-1930$}

In view of these circumstances, neonaticide may be seen as inevitable in some small percentage of cases involving women of this era who faced an unwanted pregnancy. The criminal justice system's response to these women indicates a sensitivity to the various factors that contributed to the demise of these infants, and judges and juries manifested a consistent unwillingness to view the infants' mothers as bearing the sole responsibility for their deaths. One scholar of infanticide in Canada notes that " $[\mathrm{t}]$ he most striking thing about these murder trials is the tenacity with which juries persisted in acquitting women charged with infanticide." 77 There is little reason to believe that the circumstances surrounding Canadian infanticide cases-poor, isolated, single women, who perceived themselves as having few options for supporting themselves and their child-differed from those in the United States. Indeed, Professor Lawrence Friedman suggests that "some American cases were strikingly similar to British ones." 78 Evidence for this proposition is the proliferation of statutes both in England and in the States punishing the crime of concealing the birth and death of a child. These laws provided prosecutors with an alternative route to conviction in the many cases in which it was impossible to know whether an infant had been born alive, and therefore whether it had been murdered. In addition, the statutes provided judges and juries who were inclined toward lenience against infanticide defendants with an alternative to outright acquittal.

The cases in the Chicago database seem to reflect the trend toward lenience. Of the eleven cases in which a legal outcome was reported, there was only one conviction. Ms. Elsie Sarkody, age twenty-four, was sentenced to fourteen years in prison when her

${ }^{75}$ According to one historian, in medieval Europe, married women so often escaped prosecution for infanticide that " $t$ ] hey could kill their infants with relative impunity." Kathryn L. Moseley, The History of Infanticide in Western Society, 1 Issues L. \& Med. 345, 357 (1986).

${ }^{76}$ See Chicago Homicide Database, supra note 39, Case Nos. 1225 and 10,120.

${ }^{77}$ Backhouse, supra note 67, at 461 (describing the desperation that infuses the circumstances surrounding Nineteenth Century cases involving mothers who killed their children).

${ }^{78}$ Lawrence Friedman, Crimes of Mobility, 43 STAN. L. REv. 637, 655 (1991).

${ }^{79}$ See Oberman, supra note 3, at 9-10 (providing a history of these laws). 
newborn infant was found dead in a privy vault. ${ }^{80}$ The remainder of the neonaticide cases reporting legal dispositions indicate acquittals and grand jury no bills. ${ }^{81}$

My efforts to track these Chicago cases through court documents and newspaper coverage proved futile. However, I did undertake a search of appellate court cases involving neonaticide from 1870 to 1930. As appeals, these cases cannot be viewed as representative of the general treatment of neonaticide in the courts. Nonetheless, they are interesting reflections of the attitudes of judges and juries toward those found guilty of committing this crime. Using searches similar to those undertaken in my contemporary infanticide research, I identified twenty-three cases of neonaticide arising in the United States, as reported by state appellate courts during these years. ${ }^{82}$

These cases reflect a broad range of responses to neonaticide, with penalties ranging from the death sentence to acquittal. Several interesting trends may be observed in the cases. First and foremost, regardless of the basis for the appeal, the judges seemed to be extremely interested in and influenced by the defendant's explanations for her actions. For instance, Emma Ellison was sentenced to life imprisonment in connection with the killing of her newborn. ${ }^{83}$ The state offered no testimony to show that the child was born alive, and thus, the appeal centered on the issue of corpus delicti. Nonetheless, the court, in reversing the conviction, reported at length the testimony of the defendant's mother that "[s]he was always a nervous child, was never bright, and acted like she did not have good sense." $" 84$

A second interesting pattern in these cases is the relatively harsh treatment accorded to men accused of killing the newborn babies that they fathered out of wedlock. Again, the judges in these cases seem quite moved by the circumstances surrounding the crimes. For example, the case of Mr. West Tune of Texas involved a man accused of impregnating his sister-in-law, and then murdering the newborn child conceived as a result of their liaison. ${ }^{85}$ The court found no prejudicial error in the state's claim to the jury that "defendant had debauched the said Bertie Jones, and made her a household

${ }^{80}$ Chicago Homicide Database, supra note 39, Case No. 2307.

${ }^{81}$ See id., Case Nos. 206, 291, 1225, 2315, 3710, 5107, 9050, 9240, 9249, 10,120.

${ }^{82}$ See Oberman, supra note 3, at 22 (describing this search technique).

${ }^{83}$ See Ellison v. State, 127 S.W. 542 (Tex. Crim. App. 1910).

${ }^{84} \mathrm{Id}$. at 542.

${ }^{85}$ Tune v. State, 94 S.W. 231 (Tex. Crim. App. 1906). 
drudge." ${ }^{86}$ The court upheld Tune's life sentence, rejecting his claim that Ms. Jones had had another sexual partner who had equal motive to kill the baby. ${ }^{87}$

Finally, it seems that the courts were aware, at least in some cases, that their judgments in neonaticide cases were quite vulnerable to emotionality. In the case against Sarah Jeffreys, the Supreme Court of North Carolina upheld a death sentence against the defendant, who was convicted of choking and strangling her newborn child. ${ }^{88}$ Judge Henderson ended his opinion by noting that:

The case of Sarah Jeffreys furnishes another instance of the difference of opinion which men will form of the same transaction, even upon the same evidence, at difference times. She was tried a few months after the death of her child, and whilst the prejudice ... was in full force. Elizabeth Combs was indicted as an accomplice in the murder, and convicted also: but the Court granted a new trial .... This was twelve months after the conviction of Sarah Jeffreys, when prejudice had died away, and the whole case was examined without feeling. Upon this trial the Court and the Jury were of opinion that the evidence scarcely afforded a presumption of guilt in the principal, and, of course, the accomplice was acquitted. $^{89}$

Consistent with the tendency toward lenience in these cases, the judge then noted that the governor of North Carolina ultimately pardoned Ms. Jeffreys. ${ }^{90}$

\section{HOMICIDE-SUICIDE DESCRIBED}

After neonaticide, the second most common fact pattern among the Chicago cases in which mothers killed their children were homicide-suicides. Thirty-eight of the 185 cases of mothers who killed during this era - a full twenty percent—involved mothers who killed their children and themselves. ${ }^{91}$ In comparison to contemporary cases in which similar homicide-suicides are exceedingly rare, this pattern is quite surprising. Indeed, if one leaves aside the neonaticide

${ }^{86} \mathrm{Id}$. at 232.

${ }^{87} \mathrm{Id}$. at $232-33$.

${ }^{88}$ State v. Jeffreys, 7 N.C. 480 (N.C. 1879).

${ }^{89} \mathrm{Id}$. at 482 , n.al.

${ }^{90} \mathrm{Id}$.

9I In an additional five of the cases in the Chicago database, the mothers attempted suicide after having killed their children, but failed to kill themselves. See Chicago Homicide Database, supra note 39, Case Nos. 4626, 4673, 4785, 9772, 10,310. 
cases, a full eighty-four percent of mothers who killed their children between 1875 and 1920 also committed suicide. ${ }^{92}$

These cases are strikingly similar to one another in terms of the manner of death. Virtually all of the mothers killed themselves and their children in their homes, by asphyxiation from the gas jets on their stoves. In addition, the circumstances surrounding these crimes likewise are remarkably patterned. These women typically did not kill their husbands or their older children. ${ }^{93}$ Instead, their acts generally took place when their husbands and older children were away from home. They left suicide notes in which they explained their actions as reflections of maternal love, undertaken due to despondency over abandonment, impoverishment, and/or ill health. For example, in 1918 Mrs. Mary Panzella killed herself and three of her five children (ages four, three, and eighteen months) after her husband abandoned her and moved to New York with another woman. ${ }^{94}$ Newspaper accounts indicate that, since her husband's departure, she had been dependent upon her father-in-law for support, and that she had spoken to neighbors about her intention to take her life. She had twenty-seven cents in her purse when police discovered the bodies. ${ }^{95}$

Fathers also killed their children during this era, and the database reveals numerous cases in which this occurred. There are forty-four cases in the database involving fathers who killed their children. Like the mothers, the fathers often killed themselves-twenty-five percent of these cases involving fathers were homicide-suicide, in addition to two cases of attempted homicide-suicide. ${ }^{96}$ One distinction is that in sixteen percent of the cases involving fathers who killed, the fathers killed the mothers as well as the children. ${ }^{97}$ None of the mothers who killed their children killed or even attempted to kill their husbands. A final distinction is the presence of physical abuse and violence in the deaths of children at their fathers' hands. In many of these cases, the

92 Jeffrey Adler, "I Loved Joe, but I Had to Shoot Him," Homicide by Women in Turnof-the-Century Chicago, 92 J. CRIM. L. \& CRIMINOLOGY 867 (2002) (forthcoming in this issue).

${ }^{93}$ This is in contrast to murdering fathers who more often killed entire families, including their wives. See id.

${ }^{94}$ Chicago Homicide Database, supra note 39, Case No. 4787.

${ }^{95}$ Four Lives Pay for His Love of 'Other Woman, ' CHI. TRIB., Jan. 24, 1918, at 1.

${ }^{96}$ See Chicago Homicide Database, supra note 39, Case Nos. 395, 669, 1055, 1936, 2087, 2684, 5173, 5259, 6247, 10,229, 10,285, 4667 (attempted suicide), 10,382 (same).

${ }^{97}$ See id., Case Nos. 4127, 6247, 9683, 10,285, 10,520, 10,641, 11, 105. 
children's deaths were clearly the unintended result of the fathers' sudden violent outbursts. ${ }^{98}$

As was the case with neonaticide, the rich historical record from this era helps to provide a backdrop against which we might understand these crimes. In large part, these desperate acts may emerge as comprehensible in view of the fact that, during this era, there was no social safety net for women and children. There was no governmentsubsidized food, housing, clothing, or heating available to shelter vulnerable families in times of need. Until the 1820 's, disorderly "outdoor relief" funds for the poor were provided in communities; these were all but extinguished with reforms and the passage of begging laws. Progressive reformers pushed for mothers' aid laws, first passed in 1910 by Illinois, and followed by other states. These pensions, aimed particularly at widows, were meager, stigmatizing, and strictly provisional on how closely the mother could conform to white, native-born standards of housekeeping and parenting. ${ }^{99}$ Permanent federal welfare programs did not begin until the 1930's, as part of the Social Security Act, and even then were targeted toward men who were retired or out of work. Aid to Dependent Children (ADC) was part of the 1935 Act, which was designed to assist children who experienced the death, absence, or incapacity of a parent or guardian. ${ }^{100}$ Similarly, there was no subsidized access to health care for adults or for children. Private health insurance did not come into existence until 1927 and was not widely available until several decades later. ${ }^{101}$ Moreover, from its inception, private insurance was offered as an employee benefit, rather than a government entitlement, and as such, did little to help mothers and children who did not participate in the full-time workforce.

Given the inadequacy of women's wages, as well as the absence of reliable daycare options, it is easy to see how a family might be completely devastated as a result of the death or departure of the male breadwinner. The added stress that illness brings to this equation, whether in the mother or in one of her children, is readily apparent. As a result, widows and abandoned wives often relied upon charity

\footnotetext{
${ }^{98}$ See, e.g., id., Case Nos. 1005, 3639, 5287, 8789.

${ }^{99}$ Carol Sanger, Separating From Children, 96 CoLum. L. REv. 375, 408 (1996); see also GORDON, supra note 70.

${ }^{100}$ ADC became Aid to Families with Dependent Children (AFDC) in 1962, "when Congress passed a limited program for households with an unemployed father." See ABRAMOVITZ, supra note 70, at 16.

${ }^{101}$ See generally Paul Starr, THE Social TRanSformation of American MEdicine (1982) (describing the evolution of private health insurance in the United States).
} 
from their families or from private sources in order to support their children. ${ }^{102}$

Although private charities were aware of these vulnerabilities among households headed by women, the "assistance" they offered was remarkably punitive in nature. Formed in the 1880's, the Private Societies for the Prevention of Cruelty to Children essentially were the forerunners of state departments of family services. ${ }^{103}$ Wealthy society matrons and gentlemen who were horrified by conditions of poverty ran these societies. In large part, their interventions consisted of deciding whether to remove children to orphanages or permit them to remain at home with a "warning" to the mother that, if her circumstances did not improve, the children would be taken from her. Even though the early decades of the Twentieth Century witnessed an increased professionalization of the child welfare movement by the development of professional social workers, the agencies continued to offer little support for poor mothers and their children outside of the threatened loss of custody.

Of course, the vast majority of mothers who found themselves in these desperate circumstances found ways to survive. They became employed, they borrowed money, they identified friends and relatives to care for their preschool-aged children, and they salvaged clothing and food from others' castoffs. Only the most vulnerable and the most despondent chose homicide and suicide as a way out. Their depression, anxiety, and desperation-seemingly rational responses to their circumstances-might nonetheless have been alleviated had they had access to mental health services. But there were no such services available to non-wealthy women of that era. This is somewhat ironic, in light of the outpouring of concern over women's fragile mental health among the upper classes. Particularly in the early decades of the Twentieth Century, depression was widely diagnosed among socially elite women, who often were ordered to undergo a "rest cure."104

102 See, e.g., Chicago Homicide Database, supra note 39, Case No. 9839, in which Mrs. Giovanna De Rorre, a widow with three children, killed herself and her children due to her despondency over her husband's death. The local chapter of the American Legion had collected $\$ 100$ for the family a month earlier, when it learned of their impoverishment and trouble, but the suicide note indicated Mrs. De Rorre's ongoing fear that she would be separated from her children. See Widow of Vet Kills Self and Three Children, CHI. TrIB., May 11, 1930 , at 7 .

103 ANthony Platt, The Child Savers 108-109 (1969).

104 See Dierdre English \& Barbara Ehrenreich, For Her OWN Good: 100 Years of THE EXPERTS' ADVICE TO WOMEN 131-33 (1978) (describing the medical profession's tendency to view women's rejection of traditional gender roles as a form of illness, to be treated 


\section{SOCIETAL RESPONSES TO HOMICIDE-SUICIDES}

Although cases of homicide-suicide committed by mothers were relatively common among cases involving women who killed their children during this era, they nonetheless shocked and upset Chicago society. The stories received front-page coverage in the local papers, and the articles tended to place direct blame on the husband, where relevant, and on mental health issues, where not. For example, the headline of the Chicago Tribune's coverage of the 1918 homicidesuicide involving Mrs. Josie Panzella reads: "Four Lives Pay for his Love of 'Other Woman,' Wife and 3 Children Won't Bother Errant Father Any More." 105 Likewise, the coverage of Mrs. Catherine Fisher's homicide-suicide, in which she killed her two sons, leads with a description of the suicide note, in which she stated that she "couldn't find enjoyment in anything." 106 The brief article goes on to note that Mrs. Fisher had been despondent over a lingering illness, and that she had been without sleep for three weeks. ${ }^{107}$

Among the five cases in the Chicago database in which the mothers succeeded in killing their children but survived their suicide attempts, there were no convictions. Instead, the mothers were viewed as mentally ill and generally were sent to insane asylums for treatment. In the one case in which a surviving defendant was presented to the grand jury for indictment, the jury returned a no bill. ${ }^{108}$ Indeed, my search of appellate cases nationwide during this era failed to identify a single case involving the conviction of a mother who killed her children in a failed attempt at homicide-suicide. In light of the consistent inclination to view these women's actions as the product of desperation and mental illness rather than depravity and evil, I believe this society would have found the contemporary criminal justice system's tendency to prosecute, convict, and incarcerate these women cruel and unjust. ${ }^{109}$ Indeed, I suspect they would have found

with isolation and rest); see also Charlotte Perkins Gilman, THe Yellow WallPaper (1890) (vividly depicting a woman's struggle to survive this "cure").

${ }^{105}$ CHI. TRIB., supra note 95, at 1.

${ }^{106}$ Mother Kills Self and Two Sons with Gas, CHI. TRIB., Mar. 25, 1927, at 1.

${ }^{107}$ Id.

${ }^{108}$ See Chicago Homicide Database, supra note 39, Case No. 4626.

${ }^{109}$ This is not to say that contemporary society is completely in agreement with the way in which these cases are handled. Consider, for instance, the media furor generated by the Andrea Yates case in Texas in which a mother of five, suffering from significant postpartum mental illness, survived two suicide attempts and finally killed her children. Michael Granberry, We're All Home Alone. Houston Tragedy Points up the Cost of a Society of Disconnected People, The Dallas Morning News, June 25, 2001, at 1C. 
utterly incomprehensible present endeavors to seek the ultimate penalty of death against these women. ${ }^{110}$

\section{COMPARISONS AND LINGERING QUeSTIONS}

Judging from the little evidence we have about the nature of infanticide between 1870 and 1930, the crime seems to be remarkably patterned. Ironically, from what I have been able to glean from the newspaper coverage of these cases, as well as from the appellate cases, these patterns largely went unrecognized, just as they do today. No one seemed to notice that an extraordinary number of cases involving women who killed themselves and their children occurred among women of limited resources who were left alone to manage their families. The consistent fact patterns surrounding neonaticide cases, which accounted for a much higher proportion of all infanticides in this era than they do today, likewise escaped notice. Professor Jeffrey Adler's study of homicide in this era demonstrates that "policemen desperately tried to avoid broaching the subject [of neonaticide]." In spite of the high number of newborn corpses discovered by policemen every year, the total number of neonaticide cases acknowledged by police in the first decade of the Twentieth Century numbered thirteen.

One of the biggest differences between the patterns in the historical versus the contemporary cases of infanticide is the relatively small number of homicide-suicides that occur in contemporary society. In any given year, we have maybe a handful of similar cases around the country. ${ }^{112}$ What has changed, or perhaps, what are we

${ }^{110}$ See, e.g., Don Thompson, Death Penalty Politics Fail to Solve Question of How to Ensure Justice, ChI. Dally HeRaLD, Feb. 6, 2000, at 1.

"II Adler, supra note 41.

${ }^{112}$ In recent years, several cases come to mind. For instance, in the Susan Smith case a young mother killed her sons but was unable to follow through on her plan to kill herself. See Alice Steinbach, Why Mothers Kill: Two Women Confessed to Killing Their Children, and Now the Question Remains: How Could They?, BALT. SUN, Dec. 12, 1994, at D1. In the Kimura case, a Japanese-American woman's children died when their mother attempted to commit oyakoshinju, or parent-child suicide, after learning of her husband's extramarital affair. "In traditional Japanese culture, the death ritual was an accepted means for a woman to rid herself of the shame resulting from her husband's infidelity." Note, The Cultural Defense in the Criminal Law, 99 HARV. L. REV. 1293, 1293-4 (1986). Through a plea bargain between the prosecutor and her defense attorney, Kimura's homicide charge was reduced to voluntary manslaughter and she was sentenced to one year in prison, which she had already served, and five years probation with psychiatric counseling. Id. Finally, there is the case of Judy Kirby, an Indianapolis mother of ten who attempted to kill herself and her children by driving her van into oncoming traffic along a highway. See Crash Fatal to 7 a Suicide, ExSpouse Says, CHI. TRIB., Mar. 29, 2000, at 9. 
doing right? From what we know about the circumstances surrounding these historical cases, it is clear that these mothers did not kill their children out of impatience or malice. Instead, in their profound depression they became convinced that death was the best solution for themselves, and was the only way to protect their children. This motivation is not terribly distinct from that involved in contemporary cases. Nonetheless, I believe that today many mothers who have similar feelings are less likely to kill themselves or their children. Instead, they are able to get services and support from the many social and governmental agencies that exist specifically to address these problems. In addition to the federal assistance available to single mothers and children, daycare is widely available, as are a variety of mental health services."

The second major distinction between the historical and the contemporary cases involves the relative paucity among the historical cases of infanticides involving mothers (and fathers) abusing, neglecting, and intentionally killing their children. Although these cases constitute the majority of contemporary infanticide cases, the database revealed that only twelve of the 185 cases, or six percent, followed this pattern. ${ }^{114}$ It is quite possible that the actual numbers of this sort of infanticide would have been higher if counted by today's standards. In previous eras, there may have been a tendency to misdiagnose or underreport child abuse or neglect, such that a case in which a child died while bathing without supervision, or due to a parent's overzealous beating, might have been viewed as a tragic accident rather than a criminal act. Today, we frequently charge mothers with homicide in the accidental deaths of their children. ${ }^{115}$

My search of appellate cases from 1870 to 1930 identified several instances of abuse and neglect-related infanticide. For instance, in Ex parte O'Connor, Mr. O'Connor, his wife, and his wife's sister were accused of infanticide in the starvation death of the sister's baby. Mr. O'Connor had impregnated his wife's sister, and, once the baby was born, Mrs. O'Connor and her sister attempted to feed the baby on goat's milk, and then to relinquish the baby to a nurse. The baby died from malnutrition and the three were charged with mur-

\footnotetext{
${ }^{113}$ This is not to say that this safety net for single mothers is adequate to meet all of their needs. Indeed, there is ample evidence that services such as daycare and mental health treatment are in short supply, particularly for the poor.

114 See Chicago Homicide Dataset, supra note 39, Case Nos. 1371, 2367, 3196, 3276, $3545,3774,4734,5002,5220,5417,5488,11,439$.

"Is See, e.g., MEYer \& OBERMAN, supra note 3, at 95-122.
} 
der. ${ }^{116}$ A second case involved a fifteen-year-old girl, who was sent to live with her aunt when she became pregnant. After she gave birth, her mother sent her packets of powder, which the mother told her would help the baby to nurse. The defendant testified that she knew the packets were poison, because her mother had repeatedly urged her to kill the child. The defendant fed the powder to her child, and the baby died at twelve days from poisoning. In an opinion rife with racist and sexist references to the defendant, who was AfricanAmerican and unmarried, the court affirmed her life sentence for first-degree murder. ${ }^{117}$

It is also quite possible that there has been an actual increase of infanticide cases in contemporary society due to the increased incidence of maternal substance abuse, as well as to a possible increase in child abuse, generally. Substance abuse seems to be a contributing factor in many contemporary infanticide cases, as addiction, by definition, renders a parent both less attuned to and less able to respond to her child's needs. ${ }^{118}$ Indeed, as many as fifty percent of all child abuse and neglect cases referred to juvenile court involve allegations of parental substance abuse. ${ }^{119}$ There is considerable debate about whether the growing number of child abuse victims today reflects an actual rise in child abuse, or simply an increase in the frequency with which child abuse is reported. ${ }^{120}$ As' such, it is difficult to know whether we can attribute the greater number of abuse-related infanticides to an overall increase in violence towards children.

\section{CONCLUSION}

Both historically and today, patterns in infanticide are obscured by the societal inclination to respond to tragic events by identifying a single, blameworthy individual. This leaves little room in which to question the manner in which society's structural underpinnings contribute to the persistence of the crime of infanticide. Nonetheless, when one examines these cases as a whole, rather than as isolated occurrences, they form a backdrop against which we can readily understand what seems, at first blush, to be an incomprehensible act.

\footnotetext{
${ }^{116}$ Ex parte O'Connor, 3 S.W. 340 (Tex. Crim. App. 1887). On appeal, the court held that this could not be murder but was at most negligent homicide, and thus bail was possible.

${ }^{117}$ Carlise v. State, 38 S.W. 991 (Tex. Crim. App. 1897).

${ }^{118}$ See Oberman, supra note 3, at 40-42.

119 J. Michael Murphy et. al., Substance Abuse and Serious Child Mistreatment: Prevalence, Risk, and Outcome in a Court Sample, 15 Child ABuse \& Neglect 197, 207 (1991).

${ }^{120}$ See David Finkelhor, Is Child Abuse Overreported?, 48 PUB. Welfare 22 (1990).
} 
Let us return for a moment to the case of Miss Mary Stastch, set out in the introduction to this article. She emerged from county hospital alone, an immigrant, and apparently unaccompanied by her baby's father. She would have been desperately in need of food, clothing, shelter, and money. She could have sought out private charities to help her, but many of them would have refused her if her child were illegitimate. In 1911, the year of this incident, Illinois enacted Mothers' Pension laws. ${ }^{121}$ However, at this early time, they offered support exclusively to widows. ${ }^{122}$ Had she been able to prove that she was a widow, she still would have had to meet a stringent set of guidelines in order to qualify for the relatively meager assistance provided under these laws. These requirements included taking English classes, learning to cook American food, and conforming to the standards of white, middle-class, native born women in the areas of housekeeping and mothering. ${ }^{123}$ In short, she would have had to prove herself "worthy" of the aid.

Nor did her society readily embrace the offspring of women who needed to work in order to support themselves. In addition to being exceedingly hazardous to the health of young infants, most daycare centers refused to accept "illegitimate" children. ${ }^{124}$ For example, in 1889, the Chicago Orphan Asylum's official policy was that it did not accept illegitimate babies under two years old. ${ }^{125}$ Even orphanages were loath to accept children of unmarried women. ${ }^{126}$ If she had found an orphanage willing to house her child until she could support it on her own, there was no guarantee that she would be able to get her baby back. Babies frequently were "placed out" or indentured, leaving the returning mothers without recourse.

Miss Stastch's story of the baby strangling herself on her bonnet in an accidental fall from her arms is incredible, to be sure. Seen against the backdrop of her society, however, the baby's death was scarcely an accident. Indeed, it was all but inevitable that harm would befall that child.

We know relatively little about actual women who have killed their children. We cannot estimate the psychic legacy of neonaticide

${ }^{121}$ GoRDON, supra note 70 , at 62.

${ }^{122}$ Id. at $27-28$.

${ }^{123} \mathrm{Id}$. at $25-30$.

${ }^{124}$ See id. at 52 .

${ }^{125}$ Clare L. McCausland, Children of Circumstance 93 (1976).

${ }^{126}$ Id.; see also GORDON, supra note 70, at 23-24 (describing that mothers taking their illegitimate children to orphanages risked never getting them back because the orphanage would place out a child knowing the mother was alive). 
for the woman who conceals her pregnancy, labors alone in complete silence, and then abandons her newborn to die. In spite of their cruel outcome, the acts of the women involved in these cases betray a profound ambivalence about the babies they carried. The failure of these women to resolve on a course of action during their pregnancies speaks volumes about the potential their fetuses represented both for their mothers' undoing, but also for joy and unconditional love. Similarly, the women who killed their children in homicide-suicides were ambivalent about their actions, and often saw themselves as acting out of maternal love. Rather than killing through violence, these women tended to bathe and dress their babies in their best clothes, left detailed instructions about their burials, and then cradled their children gently while awaiting their deaths. ${ }^{127}$ Even some contemporary infanticide cases demonstrate that infanticide can be a "mothering" decision. Nineteen-year-old Guinevere Garcia, for example, killed her two-year-old daughter rather than send her back to live with her uncle, who had repeatedly raped and molested both herself and her mother when they were children. ${ }^{128}$ Again, we cannot know the psychological consequences for those women who survive after killing their children, but it is surely inaccurate to depict them as demons who greedily killed their children in order to secure a broader set of life options for themselves.

Infanticide is not a random, unpredictable crime. Instead, it is deeply imbedded in, and responsive to, the societies in which it occurs. The historical homicide cases provide further evidence of the fact that the crime of infanticide is committed by mothers who cannot parent their child under the circumstances dictated by their unique position in place and time. As we have seen, these circumstances vary, but the extent to which infanticide is a reflection of the norms governing motherhood is a constant that links these seemingly disparate crimes.

${ }^{127}$ See Adler, supra note 92.

${ }^{128}$ Kathryn Kahler, Women on Death Row: A Chilling Sign of the Times, Plain DEALER, May 26, 1993, at A1. 
